\title{
Transformants of Trichoderma longibrachiatum Overexpressing the $\beta$-1,4-Endoglucanase Gene egl1 Show Enhanced Biocontrol of Pythium ultimum on Cucumber
}

\author{
Quirico Migheli, Luis González-Candelas, Laura Dealessi, Andrea Camponogara, and Daniel Ramón-Vidal
}

\begin{abstract}
First, third, and fourth authors: Dipartimento di Valorizzazione e Protezione delle Risorse Agroforestali, Università di Torino, Via L. da Vinci 44, I-10095 Grugliasco, Torino, Italy; and second and fifth authors: Instituto de Agroquímica y Tecnologia de Alimentos, Apartado de Correos 73, E-46100 Burjassot, Valencia, Spain. Accepted for publication 23 February 1998.
\end{abstract}

\begin{abstract}
Migheli, Q., González-Candelas, L., Dealessi, L., Camponogara, A., and Ramón-Vidal, D. 1998. Transformants of Trichoderma longibrachiatum overexpressing the $\beta$-1,4-endoglucanase gene egll show enhanced biocontrol of Pythium ultimum on cucumber. Phytopathology 88:673-677.

Nine transformants of Trichoderma longibrachiatum with extra copies of the egll gene were studied for mitotic stability, endoglucanase production, and biocontrol activity against Pythium ultimum on cucumber seedlings. The transformants showed a significantly higher level of expression of the egll gene in comparison to the wild type under both in-

ducing and noninducing growth conditions. Transformants with the egll gene under the control of a constitutive promoter had the highest enzymatic activity. Both the endoglucanase activity and the transforming sequences were stable under nonselective conditions. When applied to cucumber seeds sown in P. ultimum-infested soil, T. longibrachiatum transformants with increased inducible or constitutive egll expression generally were more suppressive than the wild-type strain.

Additional keywords: damping-off, biological control, lytic enzymes, rhizosphere.

Trichoderma spp. are among the most promising biocontrol agents and have activity against a wide range of plant-pathogenic fungi (8,31). Mycoparasitism is considered an important mechanism of biological control and probably depends on the production of lytic enzymes including chitinases, $\beta$-1,3-glucanases, and proteases (8). Correlation between the production of chitinolytic enzymes and the suppression of fungi containing chitin as the main cell wall constituent has been demonstrated for many Trichoderma species $(7,14,15,35)$. Chitinases from Trichoderma spp. have been characterized $(12,23,24,40,41)$ and were shown to inhibit in vitro spore germination and tube elongation of a variety of fungi except Pythium ultimum, which does not contain chitin as the major cell wall component (25). The potential role of chitinase genes expressed in transgenic plants and in antagonistic microorganisms has been tested and explored in different biocontrol systems $(5,9,38,39)$.

Although there have been extensive studies of chitinases, little is known about the role of cellulolytic enzymes in the biocontrol of plant-pathogenic oomycetes, which contain cellulose as the main

establish along the developing plant roots $(1,32)$. Similarly, bean seed colonization and protection of bean seedlings against $P$. splendens by $T$. koningii were related to high levels of carboxymethyl cellulase activity in the biocontrol agent (10).

The egll gene, encoding for the EGL1 $\beta$-1,4-endoglucanase (EC 3.2.1.4) of T. longibrachiatum, has been cloned and expressed in Saccharomyces cerevisiae (21). The purpose of this study was to determine the involvement of the EGL1 $\beta$-1,4-endoglucanase from $T$. longibrachiatum in the biological control of damping-off of cucumber caused by P. ultimum (19) and to determine if enhanced disease suppression could be achieved by increasing EGL1 activity in T. longibrachiatum. EGL1 activity was increased by introducing multiple copies of the endogenous egll gene. Nine transformants and the wild-type strain CECT2606 were then tested for mitotic stability, endoglucanase production, and biocontrol activity under contained glasshouse conditions. We demonstrate that, in general, increased EGL1 activity correlates with enhanced disease suppression.
\end{abstract} cell wall component $(3,13,30)$. Early work on the biocontrol of $P$. debaryanum by Arthrobacter spp. suggested that a glucanase and a protease were involved in the lysis of mycelium (28), while studies of the mode of action of P. nunn against Pythium and Phytophthora spp. demonstrated that cellulase was produced when the mycoparasite was grown in the presence of cellulose and cell walls of oomycetes (16). A significant level of cellulase activity also was demonstrated in mutants of $T$. harzianum active against $P$. ultimum, but this trait was associated with an increased rhizosphere competence that would allow them to competitively proliferate and

Corresponding author: Q. Migheli; E-mail address: pat.veg@fileita.it

Q. Migheli and L. González-Candelas have equally contributed to the current work.

Publication no. P-1998-0513-01R

(C) 1998 The American Phytopathological Society

\section{MATERIALS AND METHODS}

Strains and media. T. longibrachiatum Rifai wild-type strain CECT2606 was used in transformation experiments and routinely cultured on malt extract agar (MEA) (E. Merck AG, Darmstadt, Germany) at $30^{\circ} \mathrm{C}$. All T. longibrachiatum transformants used in this work were previously described $(18,37)$. They were obtained by cotransformation with plasmid pAN7-1 (34), which contains the hygromycin B selective marker, and either plasmid pTLEG12 (CT series) or plasmid pPGPDEGL1 (C series). The CT transformants contain additional copies of the egll gene under the control of its own inducible promoter, whereas C-series transformants contain extra copies of the egll gene under the control of the glyceraldehyde phosphodehydrogenase gene ( $g p d A$ ) promoter of Aspergillus nidulans, which shows constitutive expression. The transformants of the $\mathrm{C}$ series still contain the native egll gene with its own promoter. 
The isolate of $P$. ultimum Trow used throughout the experiments was obtained from a cucumber seedling with symptoms of damping-off and was routinely grown on corn meal agar (CMA) (Difco Laboratories, Detroit) at $25^{\circ} \mathrm{C}$.

Plasmids. Plasmid pTLEG12 is $6.85 \mathrm{~kb}$ in size and contains a 3.8-kb SmaI-HindIII T. longibrachiatum DNA fragment that in-

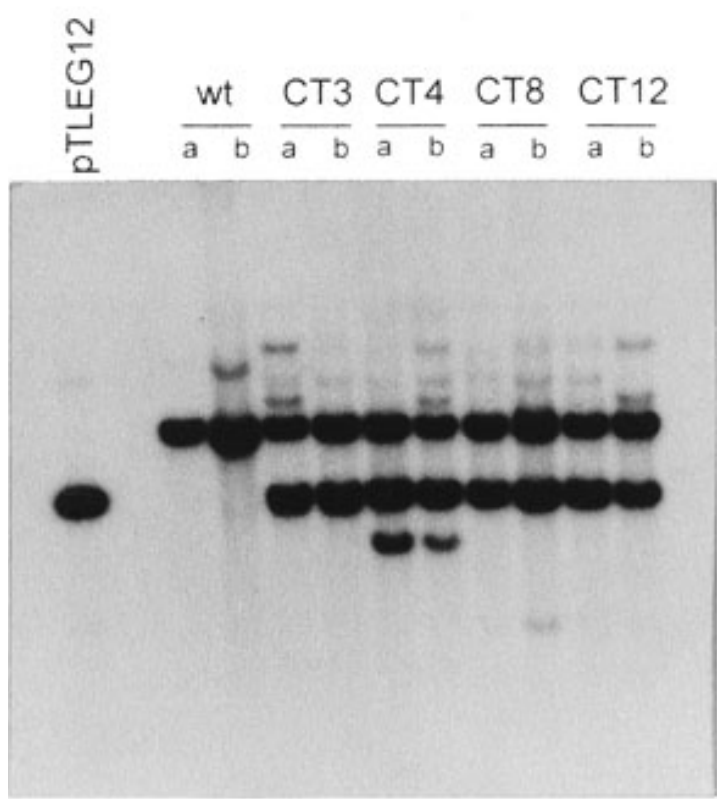

Fig. 1. Southern hybridization analysis of EcoRI/HindIII-digested DNAs obtained from Trichoderma longibrachiatum wild-type strain CECT2606 (wt) and from transformants CT3, CT4, CT8, and CT12 before "a" and after "b" passage through the cucumber rhizosphere. A 1.56-kb BamHI-HindIII fragment from plasmid pTLEGC1 containing the full-length egll gene cDNA was used as probe. The 4.2-kb hybridizing band on the left corresponds to a fragment of the pTEGL12 plasmid, which includes the egll gene with the promoter sequence.

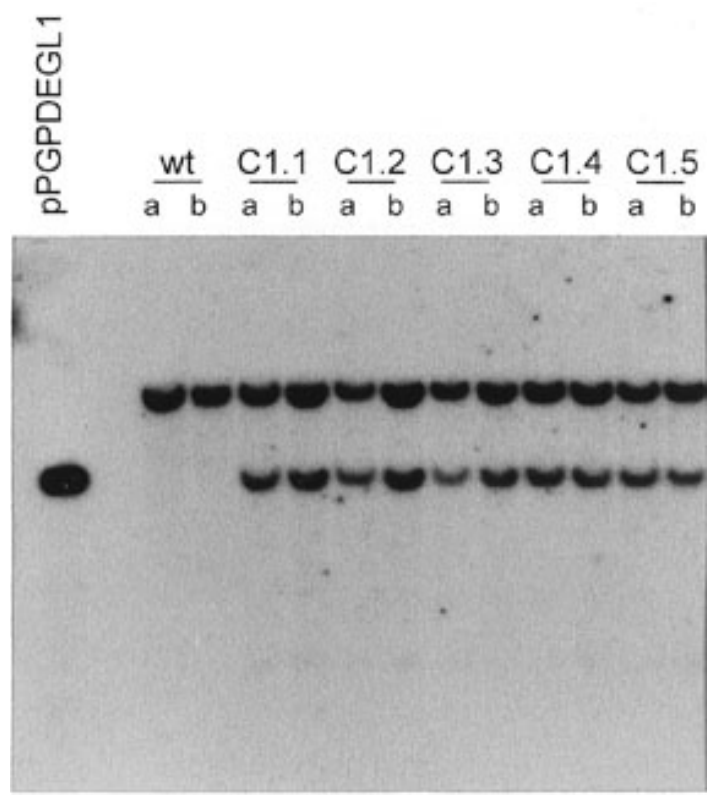

Fig. 2. Southern hybridization analysis of EcoRI/HindIII-digested DNAs obtained from Trichoderma longibrachiatum wild-type strain CECT2606 (wt) and from transformants C1.1, C1.2, C1.3, C1.4, and C1.5 before "a" and after "b" passage through the cucumber rhizosphere. A 1.56-kb BamHIHindIII fragment from plasmid pTLEGC1 containing the full-length egll gene cDNA was used as probe. The $3.8-\mathrm{kb}$ hybridizing band on the left corresponds to a fragment of the PPGPDEGL1 plasmid, which includes the egll gene with the promoter sequence. cludes the whole egll gene plus 1.1-kb upstream and 1.3-kb downstream flanking regions in a pUC13 backbone (37). Plasmid pPGPDEGL1, which is $6.47 \mathrm{~kb}$ in size, (18) contains the egll gene cDNA (from nucleotide +1 ) under the control of the constitutive A. nidulans gpdA gene promoter $(2,301 \mathrm{bp}$, up to nucleotide -1$)$ in a pUC18 backbone. Plasmid pTLEGC1 (12) contains a 1.56-kb $T$. longibrachiatum egll gene cDNA fragment cloned into pUC18.

DNA manipulations. Fungal chromosomal DNA was obtained as previously described (21). DNAs from all T. longibrachiatum strains and transforming plasmids pTLEG12 and pPGPDEGL1 were digested simultaneously with the endonucleases EcoRI and HindIII, releasing the fungal DNA from the plasmid vector, in order to distinguish the endogenous egll gene in T. longibrachiatum (which gives a band of $5.7 \mathrm{~kb}$ ) (21) from the extra copies acquired after the transformation (giving a band of $4.2 \mathrm{~kb}$ in CT-series transformants and of $3.8 \mathrm{~kb}$ in $\mathrm{C}$-series transformants). After electrophoretic separation, DNAs were transferred to a nylon membrane (Hybond N; Amersham Italia, Milano, Italy) following standard procedures (36) and fixed to the membrane with an UV crosslinker. A 1.56-kb BamHI-HindIII fragment from plasmid pTLEGC1 (21) containing the full-length egll gene cDNA was labeled with $\left[{ }^{32} \mathrm{P}\right]$-dCTP (Amersham Italia) by the random primed method according to the manufacturer's instructions and used as a probe for Southern hybridization. The presence of an internal control within each lane represented by the native egll gene, together with the use of a single hybridization probe, allowed us to calculate the plasmid copy number. The quantification of the radioactivity, measured as counts per min (cpm), present in the bands corresponding to both the native and the transforming egll gene copies was determined with electronic autoradiography equipment (Instant Imager 2024; Packard Instrument Co., Meriden, CT). Plasmid copy number was then calculated by comparing the radioactivity incorporated in the endogenous egll gene copy with the transforming one(s) within the same lane.

Enzyme activity determination. All $\beta-1,4$-endoglucanase activity assays were performed using carboxymethyl cellulose (CMC) as a substrate. One unit of endoglucanase activity corresponds to the release of $1 \mu \mathrm{mol}$ of glucose equivalent in $1 \mathrm{~min}$. Two different growing conditions were used to measure endoglucanase activity. For measuring the inducible endoglucanase activity in the pTLEG12 and pPGPDEGL1 transformants (CT series and C series, respectively), induction was carried out basically as described previously (20). Briefly, $1.0 \times 10^{5}$ spores per $\mathrm{ml}$ were inoculated into minimal medium, supplemented with $0.1 \%$ tryptone (wt/vol), and incubated in a rotary shaker $(200 \mathrm{rpm})$ (Lab-Line Instruments Inc.,

TABLE 1. Endoglucanase activity of Trichoderma longibrachiatum wild type and CT-series transformants grown under inducing condition and the copy number of the transforming pTLEG12 plasmid before and after their release in the cucumber rhizosphere

\begin{tabular}{lccccc}
\hline & \multicolumn{2}{c}{$\begin{array}{c}\text { Endoglucanase activity } \\
\left(\mathrm{mU} \mathrm{mg}^{-1} \text { dry weight }\right)^{\mathrm{x}}\end{array}$} & & \multicolumn{2}{c}{$\begin{array}{c}\text { Plasmid copy number } \\
\text { per genome }\end{array}$} \\
\cline { 2 - 3 } \cline { 5 - 6 } Strain & Before & After & & Before & After \\
\hline CECT2606 & $45.7 \pm 15.5 \mathrm{~b}^{\mathrm{z}}$ & $21.5 \pm 10.2 \mathrm{~b}^{\mathrm{z}}$ & & 0 & 0 \\
CT3 & $109.9 \pm 17.3 \mathrm{a}$ & $111.3 \pm 35.9 \mathrm{a}$ & & 1.1 & 1.1 \\
CT4 & $124.9 \pm 17.3 \mathrm{a}$ & $133.4 \pm 8.6 \mathrm{a}$ & & 1.7 & 2.2 \\
CT8 & $125.6 \pm 23.1 \mathrm{a}$ & $125.1 \pm 7.0 \mathrm{a}$ & & 1.0 & 1.0 \\
CT12 & $124.3 \pm 40.0 \mathrm{a}$ & $105.3 \pm 15.7 \mathrm{a}$ & & 1.45 & 1.0 \\
\hline
\end{tabular}

${ }^{x}$ One milliunit $(\mathrm{mU})$ corresponds to the release of 1 nanomole of glucose equivalent in 1 min under the assay conditions.

${ }^{y}$ Data represent the plasmid copy number calculated as the ratio between the counts per min (cpm) of the transforming egll gene band (present in plasmid pTLEG12) on the Southern filter and the cpm of the native egll gene band. Details in Materials and Methods.

${ }^{z}$ Values represent the mean $( \pm$ standard deviation) from three pooled experiments, with three replicates per treatment in each experiment. Values in each column followed by the same letter do not differ significantly $(P=$ 0.05 ) according to the Scheffé multiple range test. 
Melrose Park, IL) for $24 \mathrm{~h}$ at $30^{\circ} \mathrm{C}$. The mycelium was recovered by filtration, resuspended in induction medium, and further incubated for $30 \mathrm{~h}$. For measuring constitutive endoglucanase activity in pPGPDEGL1 transformants (C series), $1.0 \times 10^{5}$ spores per $\mathrm{ml}$ were inoculated in complete medium (33) containing $1 \%$ glucose and incubated in a rotary shaker $(200 \mathrm{rpm})$ for $40 \mathrm{~h}$ at $30^{\circ} \mathrm{C}$. Each experiment included three replicates, and in each replicate, all strains from each series were tested and compared with the wildtype strain CECT2606. The data from each of three experiments were first analyzed by a two-way analysis of variance $(P=0.05)$ and then subjected to the Scheffé multiple comparison test $(P=0.05)$.

Biological control of $P$. ultimum on cucumber. The biocontrol experiments were carried out on cucumber (Cucumis sativus L.) seedlings of the highly susceptible cultivar Marketer. Plugs $(1.5 \mathrm{~cm}$ in diameter) of agar were cut with a sterile cork borer from 2-dayold cultures of $P$. ultimum on CMA in petri dishes and then placed in the center of plastic pots $(10 \mathrm{~cm}$ in diameter, 1 liter capacity, one plug per pot) three quarters filled with a sterilized potting mix consisting of 1:2 sand/leaf compost (vol/vol).

To apply $T$. longibrachiatum strains, 7-day-old petri dish cultures on MEA were flooded with sterile water, and spores were scraped from the agar surface and counted in a haemacytometer. Spores were then resuspended in sterile water containing $1.4 \%$ CMC to give a final concentration of $1.0 \times 10^{8}$ spores per ml. In experiments 1 and 3, cucumber seeds were dipped for $5 \mathrm{~min}$ in the spore suspension and then placed equidistance from the center of each pot (10 seeds per pot). In experiments 2 and 4 , seeds were pregerminated in the CMC spore suspension for $24 \mathrm{~h}$ at $25^{\circ} \mathrm{C}$ before sowing. In both cases, approximately $10^{6} \mathrm{CFU}$ of each $T$. longibrachiatum strain per seed could be recovered after coating.

After the seeds were sown, the pots were filled with a $2-\mathrm{cm}$ layer of potting mix, placed on a bench in a completely randomized design (five replicate pots for each treatment) within a growth chamber at $25^{\circ} \mathrm{C}$, and watered daily by adding $100 \mathrm{ml}$ of water to each pot. Relative humidity varied between 60 and $80 \%$, and daily light conditions were maintained at 20,000 lux with a 12-h photoperiod. After 7 days, plant emergence and healthy plant stand were assessed and the data subjected to an analysis of variance followed by Duncan's multiple comparison test $(P=0.05)$.

Isolation of $\boldsymbol{T}$. longibrachiatum from cucumber rhizosphere. Two weeks after planting treated cucumber seeds, T. longibrachiatum wild-type strain CECT2606 and the nine transformants were reisolated from the rhizosphere by transferring root segments $(2 \mathrm{~cm})$ with their adhering soil to a 20 -ml glass test tube containing $10 \mathrm{ml}$ of sterile distilled water (10 segments per tube). The tubes were vortexed for $60 \mathrm{~s}$, and the T. longibrachiatum propagules present in the rhizosphere were isolated by plating serial dilutions on MEA amended with $300 \mu \mathrm{g}$ of sodium deoxycholate per $\mathrm{ml}$ (Sigma Chemical Co., St. Louis) to restrict the size of the colonies.

\section{RESULTS}

Mitotic stability and endoglucanase activity of T. longibrachiatum wild type and transformants. Transformants CT3, CT4, CT8, and CT12 were not able to sporulate in MEA containing 200 $\mu \mathrm{g}$ of hygromycin B per ml. Thus, to isolate homokaryons, mycelium plugs were transferred to plates with no hygromycin $\mathrm{B}$, and the conidia obtained from these cultures retained the resistance marker.

C-series transformants were derived from transformant C1 (18). This transformant, originally isolated in the presence of hygromycin $B$, was selected because, after several rounds of sporulation in the absence of antibiotic, it maintained constitutive $\beta$-1,4-endoglucanase activity and became sensitive to hygromycin B. Transformants $\mathrm{C} 1.1, \mathrm{C} 1.2, \mathrm{C} 1.3, \mathrm{C} 1.4$, and $\mathrm{C} 1.5$ correspond to different homokaryons obtained after conidiation of the same original heterokaryon transformant $\mathrm{C} 1$; all were sensitive to hygromycin $\mathrm{B}$ and showed constitutive CMCase activity.

Southern analyses carried out with DNAs obtained from the wildtype strain and transformants of the CT and $\mathrm{C}$ series before and after their release in the cucumber rhizosphere are shown in Figures 1 and 2, respectively. Double-digestion with EcoRI and HindIII allowed a clear differentiation between the endogenous copy of the egll gene (upper band) and that contained in the transforming plasmids pTEGL12 or pPGPDEGL1 (lower band). Extra copies of the egll gene remained relatively stable after passage of the CTseries transformants through soil (Table 1). In all transformants bearing plasmid pPGPDEGL1, there was less than one extra copy of the egll gene, suggesting that some nuclei lost plasmid sequences. The average copy number in these transformants remained constant, as no further decrease was observed after their passage through the plant rhizosphere (Table 2).

Comparison of the endoglucanase activity levels shown by $T$. longibrachiatum wild type and transformants of the CT and C series before and after their reisolation from the cucumber rhizosphere is shown in Tables 1 and 2, respectively. To identify any modification of the CMCase activity as a consequence of the passage through the host plant, data from each experiment were first subjected to a two-way analysis of variance. In all the experiments, the interaction between the two factors (strain and passage through the plant rhizosphere) was not significant (data not shown); in both series of transformants, the range of endoglucanase activity was constant, independent of the number of extra copies of the egll gene and the passage through the plant rhizosphere. In all transformants, there was a significant increase in CMCase activity in comparison to the wild-type strain CECT2606. Transformants of the $\mathrm{C}$ series had the highest endoglucanase activity when grown under inducing conditions (Tables 1 and 2).

Biocontrol activity of Trichoderma spp. against $P$. ultimum on cucumber seedlings. In the absence of the pathogen, seed treatments of T. longibrachiatum wild type and transformants did not

TABLE 2. Endoglucanase activity of Trichoderma longibrachiatum wild type and C-series transformants grown in minimal medium (inducing condition) and in rich medium (noninducing condition) and the copy number of the transforming pPGPDEGL1 plasmid before and after their release in the cucumber rhizosphere

\begin{tabular}{|c|c|c|c|c|c|c|}
\hline \multirow[b]{3}{*}{ Strain } & \multicolumn{4}{|c|}{ Endoglucanase activity $\left(\mathrm{mU} \mathrm{mg}^{-1} \text { dry weight }\right)^{\mathrm{x}}$} & & \\
\hline & \multicolumn{2}{|c|}{ Inducing condition } & \multicolumn{2}{|c|}{ Noninducing condition } & \multicolumn{2}{|c|}{ Plasmid copy number per genome ${ }^{y}$} \\
\hline & Before & After & Before & After & Before & After \\
\hline $\mathrm{C} 1.1$ & $149.1 \pm 23.3 \mathrm{a}$ & $191.7 \pm 16.7 \mathrm{a}$ & $105.6 \pm 7.9 \mathrm{a}$ & $105.5 \pm 17.3 \mathrm{a}$ & 0.85 & 0.59 \\
\hline $\mathrm{C} 1.2$ & $144.8 \pm 7.3 \mathrm{a}$ & $172.1 \pm 30.9 \mathrm{a}$ & $102.9 \pm 13.7 \mathrm{a}$ & $109.1 \pm 10.1 \mathrm{a}$ & 0.55 & 0.65 \\
\hline $\mathrm{C} 1.3$ & $148.1 \pm 4.2 \mathrm{a}$ & $180.5 \pm 34.5 \mathrm{a}$ & $103.8 \pm 10.9 \mathrm{a}$ & $107.9 \pm 14.7 \mathrm{a}$ & 0.41 & 0.44 \\
\hline C1.4 & $161.1 \pm 12.0 \mathrm{a}$ & $196.6 \pm 9.8 \mathrm{a}$ & $105.6 \pm 10.7 \mathrm{a}$ & $115.4 \pm 12.2 \mathrm{a}$ & 0.67 & 0.48 \\
\hline
\end{tabular}

${ }^{x}$ One milliunit $(\mathrm{mU})$ corresponds to the release of 1 nanomole of glucose equivalent in 1 min under the assay conditions.

y Data represent the plasmid copy number calculated as the ratio between the counts per min (cpm) of the transforming egll gene band (present in plasmid pPGPDEGL1) on the Southern filter and the cpm of the native egll gene band. Details in Materials and Methods.

${ }^{z}$ Values represent the mean ( \pm standard deviation) from three pooled experiments, with three replicates per treatment in each experiment. Values in each column followed by the same letter do not differ significantly $(P=0.05)$ according to the Scheffé multiple range test. 
affect emergence of cucumber seedlings (data not shown). In experiments 1 and 2, only 32 and $28 \%$, respectively, of the plants in the nontreated control emerged, whereas seed treatment with spores of T. longibrachiatum CECT2606 significantly increased emergence to 76 and $68 \%$, respectively (Table 3). Emergence (88 to $98 \%$ in experiment 1 and 84 to $90 \%$ in experiment 2) of cucumber treated with the four CT-series transformants tested was significantly greater than that of the wild-type or nontreated cucumber (Table 3).

In experiments 3 and 4, emergence (52 to $68 \%$ and 72 to $78 \%$, respectively) of seeds treated with transformants $\mathrm{C} 1.1, \mathrm{C} 1.2, \mathrm{C} 1.4$, and $\mathrm{C} 1.5$ of the $\mathrm{C}$ series was greater than that obtained by treating with the wild type (48\% in experiment 3 and $68 \%$ in experiment 4), although the increase was significant only for transformants C1.4 and C1.5 in experiment 3 (Table 4). Transformant C1.3 showed inconsistent performance; it did not suppress damping-off significantly in experiment 3 , but it did in experiment 4 (Table 4). The fact that seeds were pregerminated in the CMC spore suspension for $24 \mathrm{~h}$ may be responsible for triggering increased endoglucanase activity before exposure to the pathogen and, therefore, for the greater biocontrol activity of transformant $\mathrm{C} 1.3$ in experiment 4 .

\section{DISCUSSION}

The cellulase complex of Trichoderma spp. has been studied extensively, and many genes encoding cellulase have been fully characterized (29). In the current work, we analyzed nine transformants of $T$. longibrachiatum containing extra copies of the egll gene. Transformants showed a significantly higher level of gene expression and endoglucanase production as compared with the wild type under both inducing and noninducing growth conditions. When applied to cucumber seeds sown in P. ultimum-infested soil, T. longibrachiatum wild-type CECT2606 was able to reduce the incidence of damping-off. In general, transformants had significantly higher biocontrol activity than the wild-type strain against the pathogen, with the transformants of the CT series being most effective.

When grown under inducing conditions, transformants of the $\mathrm{C}$ series bearing the transforming egll gene under the control of the constitutive promoter $g p d A$ had the highest endoglucanase activity. These data are not surprising, because the cultures used in the induction experiments were obtained from a medium containing glucose as the carbon source in which the transcription of the transformant egll gene copy is activated. This transcription might still be activated during the induction experiment, resulting in double expression of both the native egll gene by its own promoter and the transforming one. Thus, transforming sequences do not seem to interfere with the natural secretion of the inducible EGL1 protein, as was suggested in the case of the native-induced $40-\mathrm{kDa}$ chitinase in T. harzianum transformants (23).

Meiotic and mitotic stability of transforming DNA in genetically modified biocontrol fungi is a basic prerequisite for any de-

TABLE 3. Effect of Trichoderma longibrachiatum CECT2606 and CT-series transformants on the emergence of cucumber seedling in the presence of Pythium ultimum $^{\mathrm{x}}$

\begin{tabular}{lcc}
\hline & \multicolumn{2}{c}{ Emergence $(\%)^{\mathrm{y}}$} \\
\cline { 2 - 3 } Trichoderma strain & Experiment 1 & Experiment 2 \\
\hline Control & $32 \mathrm{c}^{\mathrm{z}}$ & $28 \mathrm{c}$ \\
CECT2606 & $76 \mathrm{~b}$ & $68 \mathrm{~b}$ \\
CT3 & $98 \mathrm{a}$ & $90 \mathrm{a}$ \\
CT4 & $96 \mathrm{a}$ & $86 \mathrm{a}$ \\
CT8 & $88 \mathrm{a}$ & $84 \mathrm{a}$ \\
CT12 & $96 \mathrm{a}$ & $90 \mathrm{a}$ \\
\hline
\end{tabular}

${ }^{\mathrm{x}}$ Seeds were soaked in a suspension of spores of T. longibrachiatum $\left(1 \times 10^{8}\right.$ spores per $\mathrm{ml}$ ) in $1.4 \%$ carboxymethylcellulose.

y Plants were counted 7 days after sowing.

${ }^{z}$ Values represent the mean of five replicates (10 seedlings per replicate). Values in each column followed by the same letter do not differ significantly $(P<0.05)$ according to Duncan's multiple range test. liberate release into the environment (6). Enzymatic assay and Southern analyses of the transformants before and after their passage through the cucumber rhizospheres revealed that both the endoglucanase activity and the transforming sequences were relatively stable under nonselective conditions. Previous experiments were carried out with pAN7-1-transformed saprophytic Fusarium oxysporum used as antagonists in the biological control of pathogenic F. oxysporum (22). These studies showed that transformation using DNA with no homology to the recipient genome results in DNA rearrangement during in vitro growth under nonselective conditions and after recovery from soil microcosms (26). Sequence homology between the transforming plasmids pTLEG12 and pGPDEGL1 used in the cotransformation experiments and the endogenous egll gene of $T$. longibrachiatum may enhance mitotic stability of the transformants tested. A similar result was obtained with $T$. harzianum transformed with $\mathrm{pHAT} \alpha$, which carried a 2.4-kb fragment of a $T$. harzianum putative $\alpha$-amylase gene, when released onto the tomato phylloplane (27).

Because C-series transformants were under the control of the constitutive $g p d A$ promoter, we hypothesized that they should show the greatest biocontrol activity against $P$. ultimum. Moreover, the fact that transformants of the $C$ series lacked functional copies of sequences encoding resistance to hygromycin B makes them potentially more attractive as antagonists. Current regulations adopted in the European Union strongly limit the possibility of commercial production and release of microbial antagonists bearing antibiotic resistance genes, because of the potential transfer of these sequences to resident bacteria or fungi $(11,22)$. We were surprised to find that although transformants of the $\mathrm{C}$ series demonstrated greater biocontrol activity than the wild type, the difference was not always significant. Unexpectedly, the CT-series transformants showed the most consistent activity. One possible explanation is that integration of the pGPDEGL1 plasmid into the fungal genome could have altered the expression of genomic sequences, which are responsible for strain fitness. This interpretation is substantiated by the fact that all transformants of the $\mathrm{C}$ series had poor sporulation on different nutrient media in comparison to the wild type and the four CT-series transformant strains (data not shown). Therefore, the low sporulation may have reduced or abolished the benefits in terms of root colonization or mycoparasitism derived from constitutive overexpression of the egll gene.

We have demonstrated that overexpression of the egll gene can play a role in the biocontrol activity of $T$. longibrachiatum against the cellulase-containing oomycete $P$. ultimum. Additional information is now needed to evaluate the synergistic effect of other cellulase-, chitinase-, or protease-encoding genes. The improved biocontrol activity obtained by overexpression of the proteinaseencoding gene prbl in T. harzianum (17) further stresses the con-

TABLE 4. Effect of Trichoderma longibrachiatum CECT2606 and C-series transformants on the emergence of cucumber seedling in the presence of Pythium ultimum $^{\mathrm{x}}$

\begin{tabular}{lcc}
\hline & \multicolumn{2}{c}{ Emergence $(\%)^{\mathrm{y}}$} \\
\cline { 2 - 3 } Trichoderma strain & Experiment 3 & Experiment 4 \\
\hline Control & $18 \mathrm{c}^{\mathrm{z}}$ & $18 \mathrm{c}$ \\
CECT2606 & $48 \mathrm{~b}$ & $68 \mathrm{~b}$ \\
C1.1 & $54 \mathrm{ab}$ & $74 \mathrm{~b}$ \\
C1.2 & $52 \mathrm{ab}$ & $78 \mathrm{ab}$ \\
C1.3 & $36 \mathrm{bc}$ & $86 \mathrm{a}$ \\
C1.4 & $68 \mathrm{a}$ & $78 \mathrm{ab}$ \\
C1.5 & $60 \mathrm{a}$ & $72 \mathrm{~b}$ \\
\hline
\end{tabular}

x Seeds were soaked in a suspension of spores of T. longibrachiatum $\left(1 \times 10^{8}\right.$ spores per $\mathrm{ml}$ ) in $1.4 \%$ carboxymethylcellulose.

y Plants were counted 7 days after sowing.

${ }^{\mathrm{z}}$ Values represent the mean of five replicates (10 seedlings per replicate). Values in each column followed by the same letter do not differ significantly $(P<0.05)$ according to Duncan's multiple range test. 
cept that a mixture of several enzymes might be necessary for efficient cell wall lysis in the mycoparasite-pathogen interactions (4). This can be accomplished by introducing multiple lytic enzyme-encoding genes through transformation of a given biocontrol strain or, more realistically, by combining different antagonists with specific enzymatic activity (2).

\section{ACKNOWLEDGMENTS}

Research supported by the bilateral project Integrated Actions ItalySpain 89A. We thank I. Chet and A. Garibaldi for comments and suggestions and $\mathrm{S}$. Ferraris for helping in statistical analysis.

\section{LITERATURE CITED}

1. Ahmad, J. S., and Baker, R. 1987. Competitive saprophytic ability and cellulolytic activity of rhizosphere-competent mutants of Trichoderma harzianum. Phytopathology 77:358-362.

2. Baker, R. 1991. Diversity in biological control. Crop Prot. 10:85-94.

3. Bartnicki-Garcia, S. 1968. Cell wall chemistry, morphogenesis, and taxonomy of fungi. Annu. Rev. Microbiol. 22:87-108.

4. Benhamou, N., and Chet, I. 1993. Hyphal interactions between Trichoderma harzianum and Rhizoctonia solani: Ultrastructure and gold cytochemistry of the mycoparasitic process. Phytopathology 83:1062-1071.

5. Broglie, K., Chet, I., Holliday, M., Cressman, R., Biddle, P., Knowlton, S., Mauvais, C. J., and Broglie, R. 1991. Transgenic plants with enhanced resistance to the fungal pathogen Rhizoctonia solani. Science 254:1194-1197.

6. Cairns, J., and Orvos, D. R. 1992. Establishing environmental hazards of genetically engineered microorganisms. Rev. Environ. Contam. Toxicol. 124:19-39.

7. Chérif, M., and Benhamou, N. 1990. Cytochemical aspects of chitin breakdown during the parasitic action of a Trichoderma sp. on Fusarium oxysporum f. sp. radicis-lycopersici. Phytopathology 80:1406-1414.

8. Chet, I. 1987. Trichoderma-Application, mode of action, and potential as biocontrol agent of soilborne plant pathogenic fungi. Pages 137-160 in: Innovative Approaches to Plant Disease Control. I. Chet, ed. John Wiley \& Sons, New York.

9. Chet, I., Barak, Z., and Oppenheim, A. 1993. Genetic engineering of microorganisms for improved biocontrol activity. Pages 211-235 in: Biotechnology in Plant Disease Control. I. Chet, ed. Wiley-Liss, New York.

10. Cotes, A. B., Lepoivre, P., and Semal, J. 1996. Correlation between enzyme activities measured in bean seedlings after Trichoderma koningii treatment combined with pregermination and the protective effect against Pythium splendens. Eur. J. Plant Pathol. 102:497-506.

11. Day, M. J., and Fry, J. C. 1992. Microbial ecology, genetics and risk assessment. Pages 160-167 in: Release of Genetically Engineered and Other Micro-Organisms. M. J. Day and J. C. Fry, eds. Cambridge University Press, Cambridge.

12. De La Cruz, J., Hidalgo-Gallego, A., Lora, J. M., Benìtez, T., PintorToro, J. A., and Llobell, A. 1992. Isolation and characterization of three chitinases from Trichoderma harzianum. Eur. J. Biochem. 206:859-867.

13. Dietrich, S. M. C. 1973. Carbohydrates from the hyphal walls of some Oomycetes. Biochim. Biophys. Acta 33:95-98.

14. Elad, Y., Chet, I., Boyle, P., and Henis, Y. 1983. Parasitism of Trichoderma spp. on Rhizoctonia solani and Sclerotium rolfsii-Scanning electron microscopy and fluorescence microscopy. Phytopathology 73:85-88.

15. Elad, Y., Chet, I., and Henis, Y. 1982. Degradation of plant pathogenic fungi by Trichoderma harzianum. Can. J. Microbiol. 28:719-725.

16. Elad, Y., Lifshitz, R., and Baker, R. 1985. Enzymatic activity of the mycoparasite Pythium nunn during interaction with host and non-host fungi. Physiol. Plant Pathol. 27:131-148.

17. Flores, A., Chet, I., and Herrera-Estrella, A. 1997. Improved biocontrol activity of Trichoderma harzianum by over-expression of the proteinaseencoding gene prb1. Curr. Genet. 31:30-37.

18. Ganga, M. A., González-Candelas, L., Ramón, D., and Pérez-González, J. A. 1997. Glucose tolerant expression of Trichoderma longibrachiatum endoglucanase I, an enzyme suitable for use in wine production. J. Agric. Food Chem. 45:2359-2362.
19. Garrett, S. D. 1979. Pathogenic Root-Infecting Fungi. Cambridge University Press, Cambridge.

20. González, R., Pérez-González, J. A., González-Candelas, L., and Ramón, D. 1994. Transcriptional regulation of the Trichoderma longibrachiatum egll gene. FEMS (Fed. Eur. Microbiol. Soc.) Microbiol. Lett. 122:303-308.

21. González, R., Ramón, D., and Pérez-González, J. A. 1992. Cloning, sequence analysis and yeast expression of the egll gene from Trichoderma longibrachiatum. Appl. Microbiol. Biotechnol. 38:370-375.

22. Gullino, M. L., Migheli, Q., and Mezzalama, M. 1995. Risk analysis in the release of biological control agents: Antagonistic Fusarium oxysporum as a case study. Plant Dis. 79:1193-1201.

23. Haran, S., Schickler, H., Pe'er, S., Logemann, S., Oppenheim, A., and Chet, I. 1993. Increased constitutive chitinase activity in transformed Trichoderma harzianum. Biol. Control 3:101-108.

24. Harman, G. E., Hayes, C. K., Lorito, M., Broadway, R. M., Di Pietro, A., Peterbauer, C., and Tronsmo, A. 1993. Chitinolytic enzymes of Trichoderma harzianum: Purification of chitobiosidase and endochitinase. Phytopathology 83:313-318.

25. Lorito, M., Harman, G. E., Hayes, C. K., Broadway, R. M., Tronsmo, A., Woo, S. L., and Di Pietro, A. 1993. Chitinolytic enzymes produced by Trichoderma harzianum: Antifungal activity of purified endochitinase and chitobiosidase. Phytopathology 83:302-307.

26. Migheli, Q., Friard, O., Del Tedesco, D., Musso, M. R., and Gullino, M. L. 1996. Stability of transformed antagonistic Fusarium oxysporum strains in vitro and in soil microcosms. Mol. Ecol. 5:641-649.

27. Migheli, Q., Herrera-Estrella, A., Avataneo, M., and Gullino, M. L. 1994. Fate of transformed Trichoderma harzianum in the phylloplane of tomato plants. Mol. Ecol. 3:153-159.

28. Mitchell, R., and Hurwitz, E. 1965. Suppression of Pythium debaryanum by lytic rhizosphere bacteria. Phytopathology 55:156-158.

29. Nevalainen, H., and Penttilä, M. 1995. Molecular biology of cellulolytic fungi. Pages 303-319 in: The Mycota II. Genetics and Biotechnology. U. Kueck, ed. Springer Verlag, Berlin.

30. Novaes-Ledieu, M., Jiménez-Martinez, A., and Villanueva, J. R. 1967. Chemical composition of hyphal wall of phycomycetes. J. Gen. Microbiol. 47:237-245.

31. Papavizas, G. C. 1985. Trichoderma and Gliocladium: Biology, ecology, and the potential for biocontrol. Annu. Rev. Phytopathol. 23:23-54.

32. Peterbauer, C. K., Heidenreich, E., Baker, R. T., and Kubicek, C. P. 1992. Effect of benomyl and benomyl resistance on cellulase formation by Trichoderma reesei and Trichoderma harzianum. Can. J. Microbiol. 38:1292-1297.

33. Pontecorvo, G., Roper, J. A., Hemmons, L. M., McDonald, K. D., and Bufton, A. W. J. 1953. Genetics of Aspergillus nidulans. Adv. Genet. 5: 142-152.

34. Punt, P. J., Oliver, R. P., Dingemanse, M. A., Pouwels, P. H., and van den Hondel, C. A. M. J. J. 1987. Transformation of Aspergillus based on the hygromycin B resistance marker from Escherichia coli. Gene 56:117-124.

35. Ridout, C. J., Coley-Smith, J. R., and Lynch, J. M. 1986. Enzyme activity and electrophoretic profile of extracellular protein induced in Trichoderma spp. by cell walls of Rhizoctonia solani. J. Gen. Microbiol. 132: 2345-2352.

36. Sambrook, J., Fritsch, E. F., and Maniatis, T. 1989. Molecular Cloning: A Laboratory Manual. 2nd ed. Cold Spring Harbor Laboratory, Cold Spring Harbor, NY.

37. Sánchez-Torres, P., González, R., Pérez-González, J. A., GonzálezCandelas, L., and Ramón, D. 1994. Development of a transformation system for Trichoderma longibrachiatum and its use to construct multicopy transformants for the egll gene. Appl. Microbiol. Biotechnol. 41:440-446.

38. Shapira, R., Ordentlich, A., Chet, I., and Oppenheim, A. B. 1989. Control of plant diseases by chitinase expressed from cloned DNA in Escherichia coli. Phytopathology 79:1246-1249.

39. Sundheim, L., Poplawsky, A. R., and Ellingboe, A. H. 1988. Molecular cloning of two chitinase genes from Serratia marcescens and their expression in Pseudomonas species. Physiol. Mol. Plant Pathol. 33:483-491.

40. Ulhoa, C. J., and Peberdy, J. F. 1991. Purification and characterization of an extracellular chitobiosidase from Trichoderma harzianum. Curr. Microbiol. 23:285-289.

41. Ulhoa, C. J., and Peberdy, J. F. 1992. Purification and some properties of the extracellular chitinase produced by Trichoderma harzianum. Enzyme Microb. Technol. 14:236-240. 